\title{
Professional Trajectory in the Family Health Strategy: Focus on the Contribution of Specialization Programs ${ }^{1}$
}

\author{
Tatiane Aparecida Moreira da Silva ${ }^{2}$ \\ Lislaine Aparecida Fracolli ${ }^{3}$ \\ Anna Maria Chiesa ${ }^{3}$
}

This case study with a qualitative approach analyzes the professional trajectory of graduates from specialization programs in Family Health offered by the Family Health Center (FHCenter) in the metropolitan region of São Paulo, Brazil, between 2002 and 2004 identifies the contributions of this program to the performance of these professionals in the Family Health Strategy (FHS). The sample included 11 former students and data were collected through a questionnaire with semi-open questions from December 2007 to March 2008. The results revealed that six graduates no longer worked in the FHS and most of those still working in the FHS reported a low level of identification with the FHS. The program enabled changes in these professionals' daily practices, although some difficulties implementing the FHS principles into practice still remain. The conclusion is that the program positively impacted these professionals' trajectory, even though it represents a modality of training designed to complement knowledge and skills required by the FHS work.

Descriptors: Human Resources Formation; Family Health; Teaching.

\footnotetext{
${ }_{1}^{1}$ Paper extracted from Master's Thesis "Trajetória Profissional na Estrategia Saude da Familia: em foco as contribuições dos cursos de especialização" presented to Escola de Enfermagem, Universidade de São Paulo, SP, Brazil. Supported by CNPq, process \# $130228 / 2008-7$.

2 RN, Master's Student in Sciences, Escola de Enfermagem, Universidade de São Paulo, SP, Brasil. E-mail: tatyenfermagem@yahoo.com.br.

${ }^{3}$ RN, Free Lecture, Associate Professor, Escola de Enfermagem, Universidade de São Paulo, SP, Brazil. Email: Lislaine - lislaine@usp.br, Anna Maria - amchiesa@usp.br.
}

Corresponding Author:

Lislaine Aparecida Fracolli

Universidade de São Paulo. Escola de Enfermagem.

Departamento de Enfermagem em Saúde Coletiva

Av. Dr. Enéas de Carvalho Aguiar, 419

Bairro Cerqueira César

CEP: 05403-000 São Paulo, SP, Brasil

E-mail: lislaine@usp.br 


\title{
Trajetória profissional na Estratégia Saúde da Família: em foco a contribuição dos cursos de especialização
}

Trata-se de estudo de caso, com abordagem qualitativa, que teve por objetivo analisar a trajetória profissional dos egressos dos cursos de especialização em Saúde da Família, oferecidos pelo Polo Saúde da Família na Região Metropolitana de São Paulo (Polo-SF RMSP) (2002-2004), buscando identificar as contribuições do curso para a atuação desses profissionais na Estratégia Saúde da Família (ESF). A amosta foi composta por 11 ex-alunos. Os dados foram coletados através de questionário com questões semiabertas, durante os meses de dezembro de 2007 a março de 2008. Os resultados apontaram que seis ex-alunos não trabalham mais na ESF. Daqueles que trabalham, a maioria relata baixa identidade com a ESF. Participar do curso ocasionou transformações nas atividades diárias desses profissionais, embora persistam dificuldades para operar com os princípios da ESF. Conclui-se que o curso impactou positivamente a trajetória do profissional, embora represente modalidade de formação que visa complementar conhecimentos e habilidades necessários para atuação na ESF.

Descritores: Formação de Recursos Humanos; Saúde da Família; Ensino.

\section{Trayectoria profesional en la Estrategia Salud de la Familia: enfoque en la contribución de los cursos de especialización}

\begin{abstract}
Se trata de estudio de caso, con abordaje cualitativo, que tuvo por objetivo analizar la trayectoria profesional de los egresados de los cursos de especialización en Salud de la Familia, ofrecidos por el Polo Salud de la Familia en la Región Metropolitana de Sao Paulo (Polo-SF RMSP) (2002-2004) buscando identificar las contribuciones del curso para la actuación de estos profesionales en la Estrategia Salud de la Familia (ESF). Los sujetos del estudio fueron 11 ex-alumnos. Los datos fueron recolectados a través de cuestionario con preguntas semi-abiertas, durante los meses de diciembre de 2007 a marzo de 2008. Los resultados apuntaron que seis ex-alumnos no trabajaban más en la ESF. De los que trabajaban, la mayoría relata baja identificación con la ESF. Participar del curso ocasionó transformaciones en las actividades diarias de esos profesionales, a pesar de que persisten dificultades en operar con los principios de la ESF. Se concluye que el curso impactó positivamente la trayectoria del profesional, a pesar de que represente una modalidad de formación que tiene por objetivo complementar conocimientos y habilidades necesarias para actuación en la ESF.
\end{abstract}

Descriptores: Formación de Recursos Humanos; Salud de la Familia; Enseñanza.

\section{Introduction}

The Family Health Strategy (FHS) emerged in Brazil in 1994 and was conceived with the objective of organizing care practice with new foundations and criteria in order to replace the traditional care model(1). Through this strategy, the focus of attention changes from the individual to the family, which requires a professional qualified to work with this enlarged object( ${ }^{(2)}$.
The lack of professionals with appropriate training and a generalist profile to work in the FHS became an important obstacle to its consolidation(3). Hence, the Brazilian Ministry of Health institutionally assumed, through the Department of Health Education Management $\left(D_{E G E s}^{*}\right)$, the responsibility to reorient educational actions directed to health professionals focusing on new

* DEGEs "responsible for the proposal and formulation of policies related to professional training and development of continuing education of health professionals at the technical and advanced levels ${ }^{(4)}$. 
ways of teaching health and providing care(4).

Consequently, many actions directed to the education of health professionals have been developed with the support of the federal government aiming to qualify health professionals to work in the $\mathrm{FHS}^{(5)}$.

In this context, the DEGEs suggested the adoption of Continuing Education (CE) as a strategy to recompose education, care, management practices, and the development of policies and social control in the health field to face challenges posed in the performance of health professionals in the different scenarios presented within the Brazilian Unified Health System(4).

The concept of Continuing Health Education was adopted with the objective to turn the public health network into a teaching-learning network in the work practice $^{(6)}$. The proposal is that continuing education in health fills in the gaps left in the educational process, transforming professional practices and work organization. For that, transmitting new knowledge to professionals is not sufficient because the accumulation of technical knowledge is not the main focus of CE. In fact, CE aims to include personal aspects in the education and qualification of workers, as well as their values and ideas concerning the national health system in general.

In summary, the essence of CE is to offer students, through significant learning, the opportunity to critically reflect on their work places. Such reflections can result in improved quality of health services and strengthened teamwork and lead professionals to commit themselves to the health of the population for which they work, as well(7).

Aiming to implement the CE policies, the Brazilian Ministry of Health proposed the implementation of Family Health Centers (FH-Centers) in the mid 1990s to create spaces to develop partnerships between the public government and teaching institutions and prepare professionals to compose the FHS teams in the country ${ }^{(5)}$. The responsibilities of the $\mathrm{FH}$-Centers include the promotion of communication among actors, and cooperation among clinical, collective health, and management knowledge ${ }^{(8)}$.

The FH-Centers in the state of São Paulo were organized around five centers, one of them being in the metropolitan region of São Paulo and Santos(2).

These $\mathrm{FH}$-Centers aimed to promote actions in three fields: qualification, education, and CE. The state of São Paulo government involved most of the state public institutions of higher education (IHE) with these centers. Over time the predominant action of these Centers in the state of São Paulo was to provide introductory courses to prepare professionals to work within the FHS context. However, these courses were gradually assumed by the city health departments ${ }^{(9)}$, which meant that these centers focused their actions on specialization and residence programs.

Nonetheless, these specialization and residence programs carried little or no similarity to the original objective of the government, that is, of verifying the ability of these programs to transform daily professional practices. Although the specialization programs in Family Health are no longer a priority for the Brazilian Ministry of Health they still exist as does demand for them. However, we question whether these programs have the power to transform the practices of professionals toward the FHS requirements.

\section{Bibliographic review}

To investigate how the issue of professionals' education directed to FHS in the sphere of specialization has been discussed, a literature review was performed in the Virtual Health Library ( $\mathrm{VHL}$ ) and in the LatinAmerican and Caribbean Center of Health Sciences (LILACS) databases through controlled terminology without limitation of year of publication. Nine studies were found, two of which more specifically discussed the specialization programs.

A study was developed in 2007 with graduates of specialization programs in family health that aimed to identify, from the perceptions of these graduates, whether there was coherence among the programs, the FHS proposal, and the practical work these professionals performed. The author concluded that the perceptions of the former students were that the programs partially met the needs of the work performed within the FHS purview $^{(2)}$.

Another study analyzed was an article published in 2004. It evaluated the professional practice of 151 graduates of specialization programs in the collective health field in Mato Grosso do Sul, Brazil between 1986 and 1998. The authors concluded that the programs positively transformed those professionals' practices $^{(10)}$.

A search was also performed in the Latin-American Journal of Nursing between 2007 and 2009 and resulted in four articles related to the theme. None of these articles specifically discussed the specialization programs. However, one article addressed the CE proposal in the scope of the Regional Center for Continuing Education in the West of Paraná. The authors sought to identify the 
situation of health professionals working in the public service network within the $10^{\text {th }}$ Health Region and also identify the educational activities they took part in between 2004 and 2006. Only 16.2\% of the respondents had a bachelor's degree; most of the professionals completed secondary. The authors concluded that most of the workers in primary health care attended some type of educational program during the evaluated period. However, the implementation of knowledge acquired from these programs was not always possible due to organizational and managerial issues and also conflicts existent between patients and health professionals and among the professionals themselves ${ }^{(11)}$.

The relevance of this study is due to the lack of literature addressing the evaluation of specialization programs and also the exceptionally divergent results found in the studies analyzed. It investigates the contribution of specialization programs in reorienting the practices of FHS professionals.

\section{Objective}

This study analyzes the professional trajectory of graduates from the specialization programs in family health offered by the $\mathrm{FH}$-Center in the metropolitan area of São Paulo, Brazil (2002-2004) and identifies the contributions of the program to the practice of these professionals in the FHS.

\section{Method}

This is a case study with a qualitative approach. A case study can be defined as an empirical investigation of a contemporary phenomenon within a real life context, when the boundary between the phenomenon and the context is not clearly evident and where multiple sources of evidence are used(12).

The empirical bases of this study were six specialization programs in Family Health, administered in the FH-Center of the metropolitan region of São Paulo, Brazil and their 259 graduates.

Based on the students' school records, former students were contacted and informed that the data collection instrument, with open and closed questions, was available online at the State Health Department site. The questionnaire was composed of four parts with questions addressing: profile, work experience, education, current job, specialization program in family health, and plans for future job and education. Each part could be independently completed but participants had to follow a sequential order.
For the individuals to answer the questionnaire, they should access the site www.pesquisapsf.saude.sp.gov. br, and click on the 'first access' link that displayed the project presentation letter and invitation to participate in the study. Then, a free and informed consent form would be generated and offer options for the individual either to accept or refuse participating in the study; anonymity was also ensured. In the case of a positive answer, access to the questionnaire was granted. The questionnaires remained available from December 2007 to March 2008. One of the difficulties presented by this data collection instrument was the fact it was very long with an estimated time of 40 minutes being necessary to complete each part.

A total of 153 students of the 259 students who completed the programs were located. Of these, only 11 completed up to the last part of the questionnaire. The collected answers were organized in a database using Microsoft Excel. Since the number of respondents was small, information was qualitatively analyzed. For that, the strategy used was the case report, that is, multiple cases (personal trajectories) related to a single case (specialization program's graduates) are presented(12).

This study was submitted to and approved by the Research Ethics Committee at the University of São Paulo, Nursing School (CEP/EEUSP process no 597/2006).

\section{Results and Discussion}

\section{The socio-demographic characteristics of graduates- cases}

This study identified that the studied graduates were mainly women, born in the state of São Paulo, Brazil, older that 40 years of age, graduated from private universities (in medicine or nursing) more than 20 years ago. Another characteristic is that most of them had attended previous specialization programs in addition to that of family health. Some of the graduates had more than two specializations although others had only attended the specialization program in family health. The specialization programs were in diverse fields and only three of the 11 studied individuals had attended a specialization program in Public Health. None of the individuals had a master's or a doctoral degree.

All participants had access to the internet: five of them had this access at home and at work, four only at home, and the other two at work only.

The profile of these graduates in terms of time of graduation is similar to that found in a study addressing graduates of residence programs in family 
health administered in 2005. The author noted that the individuals had graduated more than 15 years ago. Despite the time of graduation, some had not attended specialization programs, while others had specializations in fields not related to family health ${ }^{(9)}$. It reinforces the importance of discussing this field during the undergraduate program; otherwise it becomes increasingly difficult changing conceptual paradigms after years of work experience.

\section{The graduates' trajectory: before, during and after the specialization program}

Six of the 11 studied cases no longer worked in the same primary health care service in which they worked at the beginning of the program, while four still worked in the same unit. The answer of one person was not clear in regard to this aspect. Of the six individuals not working in the same primary health care service, three were nurses and the other three were physicians.

All this study's respondents reported they had attended the introductory course to FHS. However, eight people attended the clinical qualification in life cycles and three did not. In relation to preceptorship in Family Health, nine individuals reported they had not had this experience while two reported they had.

Based on the graduates' reports, three of the 11 studied cases did not attend clinical qualification in life cycles but were nevertheless indicated to the specialization program. This fact affected the expectations of these professionals in relation to the specialization program. They expected that the program would provide the content they missed for not having attended clinical qualification in life cycles.

Another aspect identified in the cases refers to the reasons the participants alleged to have left the primary health care services where they used to work. In the reports of professionals who no longer work in the FHS, one individual did not want to explain the reason he left and two reported other reasons. For these last two, the work in the FHS is exhausting, causes illnesses, low selfesteem, fear, and is characterized by power struggles and burdens, especially for the physicians.

Of those who were still working in the FHS, six worked in primary health care services that are exclusively FHS and one works in a mixed primary health care service. The health teams to which four of the individuals belonged were responsible for about 600 to 1,000 families and the teams of the other three individuals were responsible for about 1,000 to 1,200 families.
Three of the studied cases directly participated in educational activities and in health promotion activities in the community, visited patients at home, performed health surveillance activities, and personally collected material for pap smear tests. One of the professionals reported that for individual consultations, he also visited patients at home; two other individuals visited patients at home and provided health education, while one of the participants did not informed which activities were planned for doctors and nurses in the FHS for which he worked.

It is important to stress that one's competence is related to one's capacity to solve problems given situations, skills, behavior, and coping strategies to deal with unpredictable situations. This study reveals that the participants resist the generalist mode of practice and have difficulties putting into practice actions consistent with the FHS.

The analysis of this career trajectory allows us to project that there is considerable turnover among the studied professionals because half of the individuals reported they were no longer working in the same primary health care service. This turnover may be considered a factor affecting the sustainability of the FHS because it ruptures the integration of the team. If such a difficulty is not overcome, especially in terms of acknowledging the work performed by the different health professionals who compose the team, there is a risk of going back to the previous health model (biological and fragmented focus). Hence, high turnover of both nurses and physicians poses a risk to the primary FHS goal - changing the health care model ${ }^{(13)}$.

A study carried out in 2005 indicates that there is a correlation between physician turnover and satisfaction at work. The results of this study indicated that a higher correlation was found between turnover and qualification: the professionals felt unqualified to carry out duties assigned to them by the FHS, which led to turnover. That study made clear that salaries attract physicians to work in the FHS, however these are not sufficient to keep them. In addition, the author identified that the level of turnover is higher among physicians than among nurses ${ }^{(14)}$.

Another study conducted in 2007 identified that the majority of the studied nurses and physicians continued working in the same primary health care service after the program, whether as a member of the team or as a manager. It seems there is not a single turnover pattern in the FHS. However, even though the specialization program is linked to the health services, it does not 
impact the professionals' turnover rate, and it is up to those responsible for this strategy of qualification to devise alternatives for $i^{(2)}$.

The critique of the specialization programs that these individuals attended is that even though these programs were developed within the FH-Centers, it seems there was no cooperation between the universities and the primary health care services in which these individuals worked at the time they were attending the program. This lack of cooperation/connection goes in the opposite direction of that expected by the National Policy on Continuing Health Education (2004), which stipulates that the following stages of training of Family Health teams should include: introductory course, clinical qualification in life cycles and the specialization program in Family Health, in this order(4).

An evaluative study conducted in $2008^{*}$ indicates that different mechanisms or modalities of programs are adopted and offered to qualify professionals who work in the FHS and the main ones are: in-service training; updating and/or improving programs; specialization programs; specific programs such as information technology and informatics; graduate programs; and programs addressing the life cycle ${ }^{(15)}$.

According to the authors of this study, the institutions responsible for ensuring these qualifications are the city health departments and most of the coordinators believe that the offered qualification processes are appropriate but insufficient to guarantee that the needs of the population and of the service are met. There are also obstacles to the qualifications of the FHS professionals such as insufficient number of programs; insufficient slots in the programs; high turnover of professionals in the family health teams; difficulty in releasing professionals during work hours to participate in the programs; difficulty in integrating the programs' content into the work routine of the primary health services; and also difficult access to the places where the programs are offered ${ }^{(15)}$.

A study conducted in 2007 makes clear that one of the expectations of graduates from specialization programs is that these programs were more practical, more succinct, and focused on prevalent and priority problems, that is, they expected these programs to re-address the specific contents of the introductory course to FHS and clinical qualification in life cycles. The author states that for those participating in the study, the specialization program only partially met their work needs and also indicated the need of professors to have experience in the work performed in the $\mathrm{FHS}^{(2)}$.

Taking into account that the FHS requires health professionals to be prepared to work within a generalist practice, consistent with the reality and needs of its work routine, more than experienced professors, the specialization programs need to offer pedagogical strategies that provide professionals the opportunity to learn how to learn, to recognize that their work environment also represents an opportunity for a learning-teaching process.

Another issue identified in the reports is the difference between the number of families under the responsibility of professionals, understanding that this varies according to the manager or the referrals inherent to the primary health care services. It may explain the changes of health professionals from one team to another, that is, professionals may migrate from a team with more families to another with fewer families in the attempt to improve their work conditions.

\section{The contributions of the programs of specialization in family health for the training of former students that could be identified in the reported cases}

In relation to the adequacy of the program to the needs of the FHS, the participants reported that the program was too focused on care but inadequately addressed politics and management. In addition, they stated that some subjects were not sufficiently or well addressed such as urgency and emergency. The participants stated that the program should emphasize the importance of the professionals' social role in implementing equity, universality, and humanization in the SUS.

Of the six graduates still working in the FHS in family health teams, one stated that he did not observe any changes in his work place during or after the program. However, the other five reported that significant changes occurred and mentioned: the use of nursing protocols; reorganization of team activities schedules; implementation of more productive and problem-solving behavior; understanding of the territory, establishment and acknowledgement of the risks it poses; organization of the demand, planning of actions, focus on health promotion and improved care delivery; improved reception and understanding of the families.

* The study's participants were coordinators of directors of primary health care services and FHS of 61 cities in the state of São Paulo, Brazil. 
In relation to the impact of the program on the routine of primary health care services, one of the former students reported he did not notice any impact. Another stated that the knowledge acquired during the program was used for his daily practice as a manager. The other participants reported that after the program, the quality of consultations and problem-solving capacity improved. In turn, other participants reported there was important and significant impact after the program, which met the expectations of both participants, and the program improved the quality of the nursing consultation and organization of work for the graduates; in addition to improved reception and understanding of families, problem-solving capacity in the primary health care services and good implementation of what was learned into the daily practice.

The former students also stated the specialization program presented weaknesses in relation to the development of the CE proposal, which according to the official guidelines, aims to transform health practices through significant learning. It is, therefore, a process based on critical-reflective transformation of professionals concerning their work places. We perceive that the impact of the program on the participants was small, which is shown when they tell about their trajectories. In addition, despite the important transformations in their daily activities, there is still difficulty in operating within the FHS principles, which may result in turnover and in changes in work.

It is important to stress that there were critiques in relation to the program's format (a single day per week and spaced workload), which according to the graduates, is tiresome and unproductive. However, despite the reports of lack of motivation in relation to the program and FHS work, we perceived that some changes occurred in the workplace after the specialization program on Family Health. According to the graduates themselves, these changes were related to the improved quality of consultations and increased problem-solving capacity; the participant's work organization; changes and improvement in the reception and understanding of families and good implementation of what was learned during the program into daily practice.

The authors of another study carried out in 2004 reported that the specialization programs in Collective Health resulted in improved managerial practices in terms of capacity to develop and implement intervention strategies in service organization and the work process. In addition, the training positively impacted the participants' perceptions and enabled them to acquire a broadened view of Public Health and consequently to identify and analyze the needs of the services for which they worked $^{(10)}$.

Another study conducted in 2007 however, showed that there was a significant report of graduates from the specialization program in Family Health that the program was not linked to the daily routine of these professionals. In addition, in this last study, the graduates stated that the professors did not have practical knowledge concerning the context of the FHS, consequently they did not have a very realistic view of the work of these professionals, which resulted in discussions in classrooms not congruent with the context in which these professionals worked. It is important to stress that the contexts of work of these professionals are different, which also affects their comments concerning the adequacy of the program to their work needs ${ }^{(2)}$.

\section{Conclusion}

For the graduates of the specialization program in family health who participate in this study, the programs still represent a modality of training that aims to complement knowledge and skills necessary to the work in the FHS. Hence, one of the challenges for the specialization program would be to enable its students to work from a broadened perspective.

It is worth noting that the specialization programs analyzed here have weaknesses in relation to the development of the CE proposal because the impact it caused on the graduates was small and these still face difficulties working according to FHS principles. The critique of these specialization programs is that even though they were developed within the HFCenters according to the CE guidelines, it seems they were not linked to other educational practices directed to the Brazilian health system. That is, there was no cooperation between the universities and the primary health care services/FHS in which the graduates worked while attending the programs offered by the HF-Center in the metropolitan area of São Paulo, which resulted in difficulties creating partnerships to change work projects and processes in the family health units and teams.

It is believed that to improve the training of health professionals to work in the FHS, the programs' formats need to be adjusted or adapted to the reality these professionals experience. In addition to the need to incorporate discussions focused on the needs identified in the context of the work of these professionals, it is important to devise other forms of effective cooperation 
and connection among the institutes of higher education (IHE), government institutions (State and City Health Departments), and health services facilities.

The Brazilian Ministry of Health has now realized that more than investing in the specialization of already graduated professionals, it is necessary to invest in changing the education within universities. An example is the public investments in the projects and programs that alter the curricula of undergraduate programs so these are adapted to the work context of the Brazilian health system.

Some of this study's results indicate the need to consider the workplace as a space to develop teaching-learning processes, enabling the service to be concomitantly organized according to the pedagogical proposal for professional qualification.

\section{Acknowledgments}

Special acknowledgement to Dr. Ana Silvia Whitaker Dalmaso for her contributions in the development of the Master's thesis that resulted in this article.

\section{References}

1. Ministério da Saúde (BR). Reunião dos coordenadores dos pólos de capacitação, formação e educação permanente em saúde da família. Brasília (DF): Ministério da Saúde; 2006. Série D. Reuniões e Conferências. 80 p. Relatório Final.

2. Turazzi MC. A especialização em saúde da família e a pedagogia crítica. [Dissertação de mestrado]. São Paulo (SP): Coordenadoria de Controle de Doenças da SES-SP, CCDSESSP; 2007. 155 p.

3. Pierantoni CR, Varella TC, França T. Recursos Humanos e Gestão do Trabalho em Saúde: teoria para a prática. Brasília (DF): Cad RH Saúde. 2006;3(1):29-40.

4. Ministério da Saúde (BR). Secretaria de Gestão do Trabalho e da Educação na Saúde. Política de Educação e Desenvolvimento para o SUS: Caminhos para a Educação Permanente em Saúde. Brasília (DF): Ministério da Saúde; 2004. 66 p.

5. Ministério da Saúde (BR). Anais da reunião técnica dos Pólos-SF (1999). Reunião técnica Pólos-SF. Brasília (DF): Secretaria de Políticas; 2000. 84 p.

6. Ceccim RB. Educação Permanente em Saúde: desafio ambicioso e necessário. Interface (Botucatu) Comunicação Saúde e Educação. 2005; 9 (16): 161-8.
7. Secretaria de Estado da Saúde/COSEMS. Documento norteador: diretrizes para implementação da Política de Educação Permanente em Saúde no Estado de São Paulo. 2007. [acesso 28 jul 2009]. Disponível em: http://www. fnepas.org.br/pdf/diretrizes_educacao_permanente_ sp.pdf

8. Ministério da Saúde (BR). Secretaria de Gestão do Trabalho e da Educação na Saúde. Caminhos para a mudança da formação e desenvolvimento dos profissionais de saúde: diretrizes para a ação política para assegurar Educação Permanente no SUS. Brasília (DF): Ministério da Saúde; 2003. 67 p.

9. Gil CRR. Formação de recursos humanos em saúde da família: paradoxos e perspectivas. Cad Saúde Pública. 2005; 21(2):490-8.

10. Adames LAB, Andrade SMO, Barbieri AR, Tamaki EM. Avaliação da prática profissional de egressos de cursos de especialização em Saúde Coletiva: a experiência do Mato Grosso do Sul. Saúde em Debate. 2004 28(68):265-72.

11. Murofuse NT, Rizzotto MLF, Muzzolon ABF, Nicola AL. Diagnóstico da situação dos trabalhadores em saúde $e$ o processo de formação no pólo regional de educação permanente em saúde. Rev. Latino-Am. Enfermagem. 2009; 17(3)314-20.

12. Yin RK. Estudo de Caso: Planejamento e Métodos. Porto Alegre: Bookman; 2003.

13. Colomé ICS. Trabalho em equipe no Programa Saúde da Família na concepção de enfermeiras. [dissertação de mestrado]. Porto Alegre (RS): Universidade Federal do Rio Grande do Sul; 2005.

14. Campos CVA. Por que o médico não fica? Satisfação no trabalho e rotatividade dos médicos do Programa de Saúde da Família do Município de São Paulo. [dissertação de mestrado]. São Paulo (SP): Fundação Getúlio Vargas 2005

15. Viana ALÁ. Os Pólos de Educação Permanente no Estado de São Paulo. In: Viana ALÁ, organizadora. Cadernos de Atenção Básica: Estudos Avaliativos 4. Recursos Humanos na Atenção Básica, Estratégias de Qualificação e Pólos de Educação Permanente no Estado de São Paulo. São Paulo (SP): Consórcio Medicina USP; 2008. p. $105-53$ 